\title{
PELATIHAN ADVERSITY INTELLIGENCE UNTUK MENINGKATKAN KEBERMAKNAAN HIDUP REMAJA PANTI ASUHAN
}

\author{
Lisfarika Napitupulu \\ Universitas Islam Riau \\ H. Fuad Nashori \\ Irwan Nuryana Kurniawan \\ Universitas Isiam Indonesia
}

\begin{abstract}
This reserach thy to investigate the Influence of Adversity Intelligence training to life meaning among teenager in orphanage. Hypotheses proposed that possible difference of fife meaning could exist before and after Adversity Intelligence training among toenager in the orphanage.

Subjects participated in this research are 6 (six) teenager of Panti Asuhan Muhammadiyan Putra in Yogyakarta and 14-19 yoars old. Experimental design employed was Pretest-Post Test Design. Data analyzed throuh pajred sample t-test.

Research found that if o meaning differences exist h subjocts before and after training with t:-2.216 $p: 0,039$. At means that Adversity Intelligence training could increase life meaning among teenager in the orphanage.
\end{abstract}

Keywords: Ife meaning, Adversity Intelligence training

\section{Pengantar}

Manusia memiliki kebebasan untuk menentukan pilihan sikap dan tindakan yang harus diambilnya ketika menghadapi suatu keadaan yang kurang menguntungkan bagi dirinya. Apapun pilihan yang diambil, pasti memerlukan usaha dan kerja keras untuk mewujudkannya. Adanya tujuan yang ingin dicapai dari pilihan yang ditetapkan berguna untuk mengingatkan mereka apabila mulal kehilangan semangat dan merasa putus asa ketika dihadapkan pada hambatan dan kesulitan

Kehidupan akan selalu menyajikan hambatan dan kesulitan sebagai ujian dan cobaan dari Allah swt. Ini diperjelas dalam AfQur'an surat al- Baqaroh ayat 155: "Dan sungguh akan kami berlkan cobaan kepadamu, dengan sedikit ketakutan, kelaparan, kekurangan harta, jwa dan buah buahan. Dan berlkanlah berita gembira bagl orang orang yang sabar".

Kesulitan hidup bisa dialami oleh siapa saja, termasuk remaja sebagai salah satu tahapan dalam perkembangan manusla. Remaja yang dihadapkan pada kesulitan akan mudah menjadi putus asa bila a tidak memiliki iujuan hidup, harapan, hal-hal berharga yang ingin dicapai. Keadaan seperti ini membuat remaja rentan kehilangan kebermaknaan hidup.

Kehilangan makna hidup membuat manusia tidak memiliki arah dan tujuan yang jelas dalam hidupnya dan mereka tidak tahu apa yang harus dilakukan. Ketidakberhasilan 
menemukan dan memahami makna hidup akan menimbulkan rasa frustrasi dan kehampaan. Hal ini diikuti dengan kemunculan emosi-emosi negatif seperti perasaan hampa, gersang, merasa tidak memiliki tujuan hidup, merasa hidup tidak berarti, bosan dan apati (Bastaman, 1996). Perasaan negatif yang muncul akan meiemahkan sikap manusia dalam menghadapi kesulitan hidup.

Permasalahan pada remaja bisa muncui sejalan dengan pergantian status dari anak-anak menjadi remaja. Sebagai remaja, mereka memiliki tugas perkembangan yang harus dilalui agar dapat hidup normai. Lingkungan berperan membantu remaja agar mereka lebih baik dan lebih siap dalam menghadapi tugas perkembangan (Hartini, 1999). Remaja memerlukan dukungan dan pengarahan dari keiuarga untuk membantu menyelesaikan tugas-tugas perkembanganya. Keluarga sebagai lingkungan sosiai terkecil merupakan tempat di mana nilai dan norma diintemalisasi menjadi bagian kepribadian yang akan mempengaruhi sikap dan tindakan para remaja ketika menghadapi kesulitan dan hambatan. Keluarga sebagai lingkungan primer mempunyai peran penting dalam penanaman nilai dan norma bagi seorang anak yang menuju masa remaja. Rasa aman yang didapat dari keluarga pada awal pertumbuhan dan perkembangan anak, akan mendorong mereka berani untuk melakukan eksplorasi terhadap lingkungannya, sehingga anak-anak tersebut bisa mengembangkan bakat dan kemampuan yang mereka miliki. Tidak dapat dihindari, bahwa keutuhan sebuah keluarga dan terpenuhinya kualitas interaksi antar anggotanya merupakan hai yang mutlak dipertukan seorang anak agar ia tumbuh menjadi seseorang dengan keyakinan bahwa ia dapat meraih tujuan hidupnya. Anak memerlukan dorongan dari orang sekelilingnya apabila mereka merasa tidak mampu menghadapi masalah atau situasi tertentu. Dorongan tersebut tidak hanya berupa bantuan yang langsung menyelesaikan permasalahan si anak, tapi juga berupa langkah-langkah yang bisa ditempuh anak dalam menyelesaikan permasalahannya (Pumomo, 1990). Akan iebih baik jika dorongan dan dukungan yang diberikan lingkungan sekitar lebih menekankan pada proses penyelesaian masalah, sehingga anak diharapkan tetap aktif dalam menyelesaikan permasalahannya. Keaktifan sebagai proses pembelajaran berfungsi sebagai bekal ketika anak-anak tersebut memasuki masa remaja, karena para remaja tersebut mungkin akan menghadapi permasalahan yang muncul ketika mereka melaksanakan tugas perkembangannya sebagai seorang remaja.

Kenyataan menunjukkan bahwa tidak setiap anak terlindungi daiam satu keutuhan keiuarga yang bisa memenuhi kebutuhan emosional dan fisik secara optimai. Ada kondisi tertentu yang menyebabkan seseorang berada d lembaga yang bemama panti asuhan. Menurut BPKKS (Widiastuti, 1995), panti asuhan adalah sebuah lembaga untuk mengasuh, menjaga dan memberikan bimbingan pada anak dengan tujuan agar mereka menjadi manusia dewasa yang cakap dan berguna serta bertanggung jawab atas dirinya dan terhadap masyarakat dikemudian hari.

Panti asuhan berperan sebagai pengganti keluarga dalam memenuhi kebutuhan anak dalam proses perkembanganny. Panti asuhan sebagai lembaga yang menangani anak-anak yang terlantar berusaha memenuhi kebutuhan anak asuhnya baik dari segi fisik maupun psikis. Panti asuhan tidak hanya sebagai tempat penitipan, tapi juga menjadi sarana penggodokan mental agar kelak mereka mampu berdiri sendiri (Majalah Amanah. 1989). Seiring dengan pertambahan usianya, seorang remaja akan dihadapkan pada tugas perkembangan baru. Tak jarang mereka akan menemui berbagai permasalahan yang dapat berubah menjadi kesulitan ila tidak segera diatasi. Khusus untuk remaja panti asuhan, mereka memiliki tambahan permasalahan berkaitan dengan konsep diri yang negatif. Menurut Lukman (2000), konsep diri negatif muncul berkaitan dengan keberadaan anak yatim dan keberadaan panti asulhan yang melabei dirinya sebagai anak yatim yang pertu dikasihani, label yang muncul secara internai 
dan juga didukung pandangan sosial menjadikan mereka bimbang dalam menilai diri mereka sendiri. Jersild (Widiastuti, 1995) mengemukakan bahwa anak-anak yang tumbuh di panti asuhan cenderung tumbuh menjadi remaja yang kurang mampu bersikap asertif dalam mengungkapkan perasaan mereka. Sikap ini membuat remaja panti asuhan tidak dapat mengekspresikan potensi yang dimilikinya. Remaja panti asuhan diharapkan tidak membuat mereka melangkah mundur, melupakan harapanharapan mereka dan pada akhirnya menyebabkan mereka kehilangan makna hidup.

Menurut Lukas (Bastaman, 1996) seseorang yang tidak bisa mengatasi permasalahannya, tidak mengetahui apa tujuan hidupnya, tidak memiliki sesuatu yang dihargai, tidak terlibat dalam suatu aktivitas yang membuatnya merasa berati akan berakhir dalam suatu keadaan di mana ia telah kehilangan makna hidupnya. Seseorang yang tidak menemukan makna hidup adalah mereka yang mempersepsikan kehidupan secara negatif. Mereka gagal dalam menemukan kewajiban sosial yang dapat membuat mereka mengalami kehampaan hidup.

Schlesinger (Bethel, 1994) menjelaskan bahwa seseorang yang menemukan makna hidupnya akan bisa bertahan hidup, karena ia memiliki pandangan, gagasan, keberanian dalam menyelesaikan masalahnya. Kebermaknaan hidup membuat remaja mampu mengubah kesulitan menjadi peluang untuk meraih sukses. Keberhasilan ini dipengaruhi ofeh Adversity Intelligence. Adversity Intelligence adalah kemampuan seseorang dalam menggunakan kecerdasannya untuk mengarahkan dan mengubah fikiran atau tindakannya ketika ia menghadapi hambatan dan kesulitan yang merupakan salah satu sumber kesengsaraan bagi dirinya.

Adversity Infelligence disusun dan adaptasi dari teori Adversity Quotient Paul G. Stoltz. Adversity Quotient merupakan suatu kemampuan untuk menghadapi kesulitan dengan memanfaatkan potensi yang dimiliki agar bisa terus maju dalam hidup
(Stoltz,1997). Adaptasi ini dilakukan karena dari yang penulis ketahui istilah Quotient lebih tepat digunakan bila tes Adversity menghasilkan skor yang bersifat normatif. Penulis belum menemukan persyaratan ini dalam teori Adversity Quotient Paul G Stoltz. Karena maksud dari Adversity intelligence yang dikemukakan penulis terkandung dalam teori Adversity Quotient Paul G Stoltz, maka untuk selanjutnya uraian mengenai adversity intelligence didasarkan pada teori Adversity Quotient Paul G. Stoltz.

Peningkatan Adversity Intelligence diharapkan dapat membantu remaja panti asuhan mengatasi kesulitan dan hambatan, menghindarkan mereka dari sikap putus asa yang pada akhirnya mampu meningkatkan makna hidup remaja panti asuhan karena mereka menyadari bahwa hidupnya berharga dan mereka menemukan alasanalasan mengapa mereka harus bertahan hidup. Mereka menemukan sesuatu untuk diperjuangkan, dengan kata lain remaja panti asuhan berhasil menemukan kebermaknaan hidup.

Melihat pentingnya Adversity Infelligence untuk membantu remaja panti asuhan menemukan kebermaknaan hidup, maka penulis tertarik untuk mengetahui pengaruh pelatihan Adversity Intelligence terhadap kebermaknaan hidup remaja panti asuhan.

\section{Dasar Teori}

\section{Kebermaknaan Hidup}

Menurut Kamus Bahasa Indonesia Kontemporer (1991), awalan ke- merupakan kata depan untuk menandai arah atau tujuan, bermakna berarti mengandung makna. Masih menurut Kamus Bahasa Indonesia Kontemporer, kata hidup berarti terus berlangsung karena adanya sesuatu. Berdasarkan uraian di atas penulis menyimpulkan, kebermakanaan hidup adalah arah menuju sesuatu yang mengandung makna hidup. Makną hidup memungkinkan seseorang untuk melanjutkan kehidupannya, karena ia menemukan sesuatu yang beharga pada makna hidup itu. 
Menurut Frankl (Bastaman, 1997), makna hidup adalah sesuatu yang oleh seseorang dirasakan penting, berharga dan diyakinl sebagai sesuatu yang benar serta dapat menjadi tujuan hidupnya. Makna hidup bisa berupa cita-cita untuk kelak menjadi orang yang sukses dan adanya keinginan untuk itu membuat seseorang bisa bertahan hidup.

Bagi remaja panti asuhan penemuan makna hidup akan mengubah cara pandang mereka terhadap kesulitan dan hambatan yang di alami, kesulitan dan hambatan tersebut tidak menjadi stressor bagi mereka, melainkan sebuah tantangan untuk mencapai keberhasilan. Kesulitan dan hambatan bisa ditemukan oleh siapa saja dan d mana saja. Bagi sebagian remaja yang berada di panti asuhan, menjalani kehidupan bersahaja, bersahabat dengan segala keterbatasan fasilitas fisik dan non fisik seperti kasih sayang, perhatian barangkali merupakan ujian dari Allah SWT. Namun sesungguhnya ada makna yang tersirat di balik kesulitan dan hambatan yang muncul sehubungan dengan keadaan remaja panti asuhan dan akan mereka ketahui ketika para remaja panti asuhan tersebut berhasil melewati hambatan dan kesulitan itu. Keberhasilan remaja panti asuhan dalam melewati kesulitan dan hambatan akan semakin mendekatkan mereka dalam pencapaian makna hidupnya.

Frankl (Bastaman, 1996) menguraikan ada tiga aspek dari kebermaknaan hidup, yaitu: kebebasan berkehendak (freedom of wilt), kebebasan berkehendak adalah kebebasan untuk menentukan sikap terhadap kondisi biologls, psikologis, sosiokultural dan kesejarahannya. Kualitas diatas menunjukkan bahwa manusia adalah individu yang dapat mengambil jarak dari kondisi lingkungan di luar dirinya (sosiokultural dan kesejarahannya) dan dari kondisi yang datang dari dalam dirinya (biologis dan psikologis).

Aspek yang kedua adalah kehendak hidup bermakna (will to meaning), yaltu keinginan manusia untuk menjadi orang yang berguna dan berharga bagi dirinya, keluarga dan lingkungan sekitamya. Aspek yang ketiga adalah makna hidup yaitu menemukan sesuatu yang dirasakan pentlng, benar, berharga dan didambakan serta memberi nilai khusus bagi seseorang. Crumbaugh dan Maholick (Koeswara, 1992) menyatakan ada enam aspek dari makna hidup. Tiga dari aspek terse but sama dengan rumusan yang diajukan oleh Frankl, yaitu: makna hidup, kehendak hidup bermakna, kebesbasan berkehendak, kepuasan hldup, pikiran tentang bunuh diri. Ada lima faktor yang mempengaruhi kebermaknaan hidup seseorang yaitu: (a) pemahaman pribadi, merupakan kemampuan seseorang dalam mengenali keunggulan dan kelemahan yang dimilikinya, (b) Bertindak positif, menerapkan hal-hal baik dalam perilaku dan tindakan nyata sehari-hari, (c) Memiliki hubungan yang akrab, (d) Pendalaman tri nilai yaitu nilai kreatif, nilai-nilai penghayatan, nilai bersikap, dan (e) ibadah.

\section{Pelati han Aơver sity Intelligence.}

Training atau pelatihan adalah kegiatan yang dirancang untuk meningkatkan kinerja seseorang dalam pekerjaan yang diserahkan kepada mereka (Hardjana, 2001). Binet dan Simon (Azwar, 2002) merangkum pengertian inteligensi dalam tiga komponen, yaitu kemampuan seseorang dalam mengarahkan pikiran atau tindakannya, kemampuan seseorang untuk mengubah arah tindakan bila tindakan tersebut telah terlanjur dilakukan dan kemampuan seseorang untuk mengkritik diri sendiri atau melakukan autocriticism. Menurut kamus psikologi, inteligensi berarti cerdas, pandai. Menurut Kamus InggrisIndonesia (Echols dan Shadily, 1995). adversity berarti kesengsaraan. kemalangan.

Adversily intelfigence yang akan digunakan penulis dalam pelatihan ini disusun dan diadaptasi dari teori Adversity Quotient Paul G Stoltz. Adaptasl ini dilakukan karena dari yang penulis ketahui istilah Quotient lebih tepat digunakan bila tes Adversily menghasilkan skor yang bersifat normatif. Penulis belum menemukan persyaratan ini dalam teori Adversity Quotient Paul G Stoltz. Adversity Quotient (AQ) merupakan teori baru yang 
dikemukakan oleh Paul G.Stoltz. Adversity Quotient mengungkapkan seberapa jauh kemampuan seseorang dalam menghadapi kesulitan dan hambatan yang dialaminya (Stollz, 1997).

Berdasarkan uraian di atas, Adversity Intelligence merupakan kemampuan seseorang dalam menggunakan kecerdasannya untuk mengarahkan. mengubah cara berfikir dan tindakannya ketika la menghadapi hambatan dan kesulitan yang bisa menyengsarakan dirinya. Pelatihan Adversity Intelligence yang dilakukan penulis merupakan rangkaian kegiatan yang sistematis dengan tujuan untuk meningkatkan kemampuan remaja panti asuhan dalam mengarahkan, mengubah fikiran, tindakan dan mengenalkan keterampilan baru ketika ia dihadapkan pada hambatan dan kesulitan sehingga remaja panti asuhan terhindar dari rasa putus asa yang dapat menghambat pencapaian makna hidupnya.

Stoltz (2000) mengemukakan ada em pat komponen dari Adversily Quotientdan empat tahap untuk meningkatkan Adversity Quotient seseorang. Komponen tersebut merupakan materi dalam pelatihan Adversity intelligence. Komponen tersebut adalah kendali (contron), asal-usul dan pengakuan (origin dan ownership), jangkauan (reach), dan daya tahan (endurance). Keempat komponen ini akan dibahas secara bersamaan dengan tahap-tahap pelatihan Adversity intellegence. Materi pelatihan Adversity Intelligence akan disampaikan dalam empat tahap yang tersusun dalam rangkaian LEAD.

Tahapan ini disusun berdasarkan metode ABC Albert Ellis (Stoltz,1997), yaitu suatu model perilaku rationalemotif yang didasarkan pada pemahaman bahwa yang menimbulkan reaksi dan perasaan adalah keyakinan kita tentang suatu peristiwa, dan bukan peristiwa tu sendiri.

Metode yang digunakan untuk menyampaikan materi adalah experiental leaming, yaitu belajar melalui pengalaman. Peristiwa di dalam kehidupan dapat disimulasikan melalui suatu permainan yang dapat dirasakan secara langsung oleh peserta pelatihan (Ancok, 2002). IIwanto
(Nadiah, 2003) mengatakan materi dalam pelatihan dapat disampaikan dengan metode keteladanan, yang mengacu pada teori model Bandura yang berasumsi bahwa perilaku dapat dipelajari melalui observasi. Sumber model dapat diambil dari anggota kelompok, pemimpin, tamu, audio visual, diri sendir, skenario dan dari dunia nyata (Rose, 1989; Prihartanti, 1994; Nadiah 2003). Model dalam pelatihan inf dari anggota kelompok dan audio visual.

Berdasarkan uraian di atas, pelatihan Adversity Intelligence akan dilakukan dalam empat tahap. Tahap pertama adalah mendengarkan respon remaja panti asuhan terhadap masalah yang mereka alami (iisten) atau pengenalan masalah. Materi yang akan disampalkan pada tahap ini adalah Tiga tipe Manusia (Climbers, Campers, Quiters ), ARP (Adversity Response Profle), COORE (Control, Origin \& Ownwrship, Reach, Explore). Tahap kedua adalah menjajaki masalah yang dialami (explore). Materi yang disampaikan pada tahap ini adalah refleksi diri, mengetahui asal-usul kesulitan (origin) dan mengakui asal-usul kesulitan tersebut (ownership) dan diagram kognitif.

Tahap ketiga adalah menganalisis kesulitan yang dialami (analyze). Materi yang disampaikan pada tahap ini adalah mencari bukti bahwa satu kesulitan harus mempengaruhi kehidupan individu secara keseluruhan (reach), mengetahui apakah ada buktinya bahwa kesulitan harus berlangsung lebih lama dari semestinya (endurance), apakah seseorang benarbenar tidak bisa memegang kendali atas kesulitan yang dialami (control), materi kedua adalah hikmah di Balik kesulitan. Tahap keempat adalah melakukan sesuatu (do). Materi yang akan disampaikan adalah Menghentikan pikiran negatif STOP dan Proaktif. Metode yang dipergunakan dalam pelatihan ini adalah experiental learning dan metode keteladanan.

Hasil Penelitian Terdahulu. Menurut pengamatan penulis, penelitian tentang kebermaknaan hidup telah banyak dilakukan, di antaranya penelitian yang dilakukan oleh Rahman (1996) tentang hubungan antara kebermaknaan hidup dan daya tahan stres pada remaja. Dari hasil 
penelitian ini diketahui adanya hubungan positif antara kebermaknaan hidup dan tingkat daya tahan stres pada remaja. Hasil penelitian Pihasniwati (1998) tentang pengaruh pelatihan penghayatan Al-Qur'an terhadap kebermaknaan hidup menunjukkan adanya perbedaan kebermaknaan hidup pada kelompok yang diberi pelatihan penghayatan Al-Qur'an, di mana kelompok yang diberi pelatihan penghayatan Al-Qur'an mengalami peningkatan kebermaknaan hidup.

\section{Hipotesis}

Hipotesis penelitian berbunyi ada perbedaan kebermaknaan hidup antara remaja panti asuhan yang memperoleh pelatihan Adversity Intelligence dengan remaja panti asuhan yang tidak memperoleh pelatihanAdversity Intelligence.

\section{Metode Penelitian}

Subjek Penelitian. Subjek pada penelitian ini adalah anak asuh yang bertempat tinggal di panti asuhan Yatim putra Muhamadiyah, berusia antara 14-19 tahun dan memiliki kebermaknaan hidup yang terkatagori tinggi. Seluruh subjek berjumlah 12 orang dengan perincian enam orang masuk kelompok eksperimen dan enam orang lainnya masuk kelompok kontrol.

Rancangan Eksperimen. Penelitian ini memakai metode eksperimen dengan rancangan Pretest-Posttest Control Group Design. Rancangan eksperimen tersebut dapat dilihat pad a tabel di bawah ini :

Tabel 1.

Kelompok Kontrol dengan Kelompok Eksperimen

\begin{tabular}{lccc}
\hline \multicolumn{1}{c}{ Kelompok } & Pretest & Treatment & Posttest \\
\hline Kel. Eksperimen & T1 & X & T2 \\
Kel. Kontrol & T1 & - & T2 \\
\hline Rancangan Eksprimen (Suryabrata, 1992) & \\
Keterangan : & & \\
T1 : Pengukuran Sebelum diberi perlakuan & \\
X : Perlakuan yang diberikan & \\
T2 : Pengukuran Setelah diberi perlakuan &
\end{tabular}

Subjek penelitian dibagi menjadi kelompok kontrol dan kelompok eksperimen. Keduanya diberi pretest pada saat yang bersamaan. Kelompok eksperimen diberikan perlakuan selama dua hari satu malam, sedangkan kelompok kontrol diberikan perlakuan setelah post-test. Kelompok eksperimen dan kelompok kontrol diberikan posttest pada saat yang bersamaan untuk mengetahui apakah ada pengaruh pelatihan Adversity Intelligence terhadap kebermaknaan hidup

Pembagian antara kelompok kontrol dan kelompok eksperimen dilakukan dengan metode Matching-Subjects Design (Pola M-
S) (Kartono, 1986). Sebelum suatu eksperimen diadakan, terlebih dahulu dilakukan matching di antara kelompok eksperimen dan kelompok kontrol, agar kelompok kontrol dan kelompok eksperimen seimbang sehingga pada awal eksperimen kedua kelompok itu dapat berangkat dari suatu titik tolak yang sama (situasi awal yang relatifsama).

Metode Pengumpulan Data. Ada beberapa alat yang dipergunakan dalam penelitian ini guna memperlancar proses penelitian. Pertama, Skala Kebermaknaan hidup. Skala ini disusun berdasarkan gabungan dari aspek kebermaknaan hidup 
yang dirumuskan oleh Frankl (Bastaman, 1996) serta Crumbaugh dan Maholick (Koeswara, 1992) yang terkandung dalam kebermaknaan hidup. Aspek-aspek tersebut meliputi kebebasan berkehendak, keinginan hidup bermakna, makna hidup dan kepuasan hidup. Sebagian aspek kebebasan berkehendak dan aspek makna hidup merupakan adaptasi dari skala yang disusun oleh Zainurrofikoh (2000). Skala kebermaknaan hidup Zainurrofikoh memiliki koefisien korelasi total berkisar antara 0,2828-0,9191 dengan koefisien reliabilitas alpha sebesar 0, 9191. Aspek kehendak hidup bermakna disusun sendiri oieh penulis. Sebagian aspek kepuasan hidup dimodifikasi dari Purpose in life test (PL) yang disusun oleh Maholick dan Crumbaugh. Skala ini terdiri dari 45 itern yang terbagi dalam item favorable dan item unf avorable untuk tiap-tiap aspek. Pemberian nilai dalam skala ini menggunakan skala model likert dengan lima altematif jawaban (Azwar, 2002). Lima alterntif jawaban tersebut adalah Sangat Tidak Sesuai (STS), Tidak Sesuai (TS), Netral (N), Sesuai (S), Sangat Sesuai (SS). Pernyataan favorable SS diberi nilai 5 ,
S diberi skor4, N bernilai 3, TS bemilai 2 STS bernilai 1 dan sebaliknya pada pernyataan unfavorable. Setelah dilakukan analisis untuk mengetahui kesahihan alat ukur, diketahui bahwa skala kebermaknaan yang digunakan dalam penelitian ini memiliki koefisen korelasi yang bergerak antara 0,3028-0,9692 dengan koefislen reliabilitas alpha sebesar 0,9081 .

Perlakuan. Perlakuan diwujudkan dalam bentuk modul yang menjadi pemandu acara pelatihan. Modul pelatihan Aoversily Intelligence yang disusun sendlri oleh penulis berdasarkan teori Adversity Quotient Paul G Stoltz. Pelatihan Adversity intellegence terdiri dari empat tahap, yaitu mendengarkan respon terhadap kesulitan yang dialami (isten). Tahap kedua adalah menjejaki asalusul kesulitan dan mengakui akibat kesulitan yang dialami (explore). Tahap ketiga adalah menganalisis bukli tidak adanya kendali ketika dihadapkan pada kesulitan (ana/yze). Tahap terakhir adalah melakukan sesuatu untuk mengatasi kesulitan (do). Masingmasing tahap akan diisi dengan materi yang merupakan aspek Adversity Intelligence yang dimiliki seseorang.

Tabel 2

Aktivitas Selama Kegiatan Pelatihan

\begin{tabular}{|c|c|c|c|}
\hline Tahop & Mate ri & Waktu & Pelaksana \\
\hline Listen & $\begin{array}{l}\text { a.Teka-teki koin \& Pemaknaan } \\
\text { b. Tiga tipe Manusia :CCO } \\
\text { c. Cerita Bermakna } \\
\text { d.ARP } \\
\text { e. CO2RE }\end{array}$ & $\begin{array}{l}25 \text { Meni: } \\
30 \text { Menit } \\
36 \text { Menit: } \\
10 \text { Menit } \\
20 \text { Menit }\end{array}$ & $\begin{array}{l}\text { Trainer } \\
\text { Co-trainer }\end{array}$ \\
\hline Explore & $\begin{array}{l}\text { a. Reffeksi diri \& Pemaknaan } \\
\text { b. Origin \& Ownership } \\
\text { c. Diagram Kognitif }\end{array}$ & $\begin{array}{l}30 \text { Menit } \\
52 \text { Menit } \\
40 \text { Menit }\end{array}$ & Trainer \\
\hline Analyze & $\begin{array}{l}\text { a. Peleburan diri } \\
\text { b. Analisis kendall (control), } \\
\text { Jangkauan (Reach) dan } \\
\text { Daya tahan (Enduranco) } \\
\text { c. Nonton VCD Harun Yatya } \\
\text { d. Renungan } 8 \text { Pemaknaan: } \\
\text { Menapaki jalan berbatu }\end{array}$ & $\begin{array}{l}15 \text { Menit } \\
15 \text { Menit } \\
36 \text { Menit } \\
25 \text { Menit } \\
45 \text { Menit }\end{array}$ & $\begin{array}{l}\text { Trainer } \\
\text { Co-trainer } \\
\text { Observer }\end{array}$ \\
\hline Do! & $\begin{array}{l}\text { a Pohon Harapan } \\
\text { b. Role paly: Stop! } \\
\text { c Proaktif }\end{array}$ & $\begin{array}{l}25 \text { menit } \\
15 \text { Menit } \\
35 \text { Menit }\end{array}$ & $\begin{array}{l}\text { Co-trainer } \\
\text { Co-trainer } \\
\text { Trainer } \\
\text { Observer }\end{array}$ \\
\hline
\end{tabular}


Di samping modul, disiapkan juga lembar penilaian subjek. Tujuannya adalah untuk menilai jalannya pelatihan Adversity Intelligence. Selain itu, juga ada surat persetujuan subjek yang merupakan bukti bahwa subjek bersedia mengikuti pelatihan ini dengan segala konsekwensinya. Terakhir, lembar wawancara berisi pertanyaan tentang kesan peserta terhadap pelatihan, serta untuk mengetahui sejauh mana perubahan yang dirasakan subjek setelah mengikuti pelatihan.

Metode Analisa Data. Metode analisa data yang digunakan adalah $\mathrm{Uji}_{\mathrm{ji}}$ beda $\mathrm{t}$ paired sample $t$ test. Analisvadata penelitian memakai bantuan komputer SPSS Versi 10.00 for Windows.

\section{Hasll Penelitian}

Pelatihan Adversity Intelligence dilaksanakan pada tanggal 3-4 April 2004 bertempat di ruang pelatihan Pondok Pesantren Budi Mulya. Pelaksanaan kegiatan dapat dibagai menjadi tiga bagian. Pertama adalah pembukaan. Kedua, pelaksanaan pelatihan yang berlangsung dalam empat tahap dengan materi yang berbeda. Ketiga adalah penutupan. Pada saat ini peserta diberikan posttest, wawancara terpisah, penjelasan rangkaian penelitian dan perpisahan.Pretest diberikan bersamaan seminggu sebelum pelatihan. Posttest pada kelompok eksperimen dan kelompok kontrl dilakukan pada waktu yang sama ditempat terpisah. Follow up dilaksanakan 23 Mei 2004.

Adapun hasil penelitian adalah sebagai berikut:

Tabel 3.

Uji t test pada keiompok eksperimen dan kontrol berdasarkan nilal pretest dan posttest

\begin{tabular}{lcc}
\hline Kebermaknaan Hidup & $\mathrm{t}$ & $\mathrm{p}$ \\
\hline Pretest-Postest (eksperimen) & 2.216 & 0.039 \\
Protest-posttest(kontrol) & 0.148 & 0.444 \\
\hline
\end{tabular}

Tabet 4

Uf t-test pada kelompok kontrol dan Eksprimen berdasarkan nilai pretest dan Follow up

\begin{tabular}{lcccc}
\hline \multirow{2}{*}{ Kelompok } & \multicolumn{2}{c}{ Pretest - follow up } & \multicolumn{2}{c}{ Posttest - Follow up } \\
\cline { 2 - 5 } & $\mathrm{t}$ & $\mathrm{p}$ & $\mathrm{t}$ & $\mathrm{p}$ \\
\hline Kontrol & 1.137 & 0.1535 & 0.524 & 0.3115 \\
Eksperimen & -5.82 & 0.293 & 1.305 & 0.1245 \\
\hline
\end{tabular}

Hasil uji t paired yang dilakukan untuk melihat apakah perubahan rata-rata tersebut berarti secara statistik menunjukkan hasil yang signifikan untuk hipotesis satu arah $(p=0.039: p<0.05)$. Dengan demikian ada pengaruh pelatihn Adversity Intelligence terhadap peningkatan kebermaknaan hidup pada remaja panti asuhan yang diberi perlakuan. Rerata nilai pretest dan postest kebermaknaan hidup pada kelompok kontrol juga mengalami peningkatan, tapi setelah dlanalisis lebih lanjut perubahan tersebut 
ternyata tidak cukup meyakinkan secara statistik ( $p=0.444 ; p>0.05)$.

Perbandingan antara nilai kebermaknaan hidup yang signifikan pada kelompok eksperirnen setelah mendapatkan perlakuan dengan nilai keberrnaknaan hidup yang tidak signifikan pada kelompok kontrol yang tidak diberi perlakuan menunjukkan ada pengaruh pelatihan Adversity Intelligence terhadap peningkatan kebermaknaan hidup. Subjek yang mendapatkan pelatihan Adversity intelligence rnengalarni peningkatan kebermaknaan hidup. Hal ini menunjukkan bahwa hipotesis penelitian diterima. Hasii follow up untuk kelompok kontrol yang rnembandingkan nilai kebermaknaan hidup pada saat pretest-follow up dan posttest dengan follow up menunjukkan hasil yang tidak signifikan, tidak ada perbedaan kebermaknaan hidup pada kelompok kontrol. Hasil tersebut menunjukkan tidak ada perbedaan yang signifikan untuk nilai kebermaknaan hidup pada kelompok eksperimen setelah beberapa waktu materi pelatihan diberikan.

\section{Pembahasan}

Sebelum pengambilan data, nilai kebermaknaan hidup pada kedua kelompok telah diselmbangkan. Kartono (1986) mengatakan pentingnya nilai yang seimbang antara kelompok kontrol dan kelornpok eksperimen agar nantinya jika ada perbedaan di antara kedua kelornpok rnaka perbedaan tersebut semata-mata disebabkan oleh metode yang diberikan dalam eksperimen, bukan karena perbedaan kondisi awal.

Tampaknya rnateri yang disarnpaikan melalui empat tahap peningkatan Adversity Intelligence turut berpengaruh tehadap peningkatan kebermaknaan hidup remaja panti asuhan yang mengikuti pelatihan tersebut. Tahapan LEAD mencoba menanamkan kesadaran kepada peserta, bahwa yang menimbulkan reaksi dan perasaan terhadap suatu peristiwa adalah keyakinan seseorang tentang suatu peristiwa dan bukannya peristiwa its (Stoltz, 1997).
Manusia termasuk remaja panti asuhan rnemiliki keinginan dasar untuk dapat diterima apa adanya oleh lingkungan, rnenjadi yang terbaik, berhasii dalarn hidupnya. Untuk rnewujudkan semua itu akan ada harnbatan dan kesulitan yang rnuncul. Salah satu sumber kesulitan tersebut dapat muncul dari pola pikir yang keliru bahwa tinggal di panti asuhan berarti hidup dengan keterbatasan-keterbatasan. Terbatasnya sarana dan prasarana, rnisaikan kebutuhan papan (pakaian yang bagus, uang jajan yang terbatas), adanya perasaan yang terasing dari keluarga, rnasa depan yang belurn jelas. Perasaan yang tumbuh dari cara berpikir yang keliru itu dapat menimbulkan kesulitan yang akan mempengaruhi rnereka ketika mereka berinteraksi dengan lingkungan. Kesulitan ini, bila tidak teratasi akan melernahkan semangat mereka untuk iebih maju, rnencapal apa yang semula mereka cita-citakan. Keadaan seperti ini rnenyebabkan remaja panti asuhan rentan kehilangan makna hidup. Makna hidup dapat diternukan kembali melalui pelatihan Adversity Intelligence, yaitu denagn rnernperbaiki pola berfikir seseorang. Proses kognitif menekankan bahwa yang menimbulkan reaksi dan perasaan adalah keyakinan seseorang tentang suatu peristiwa dan bukannya peristiwa itu sendiri Ellis (Stoltz, 1997). Pikiran negatif yang menirnbulkan perasaan tidak berdaya yang dapat rnelernahkan semangat juang seseorang untuk mengatasi harnbatan dan kesulitan dapat diperbaiki melalui peningkatan daya juang (Adversity intelligence) seseorang.

Crumbaugh (Bastarnan, 1996) rnengatakan, salah satu rnetode untuk menemukan kembali rnakna hidup adalah dengan rnelakukan tindakan positif. Tindakan positif diawali dengan berpikir positif, di mana seseorang tetap rnampu mernainkan irnajinasinya untuk tetap memikirkan hal-hal yang baik di saat la mengalarni suatu kesultan sehingga ia tetap mampu rnemegang kendali atas dirinya. Penulis mengasurnslkan, peningkatan kebermaknaan hidup pada remaja panti asuhan setelah mereka mengikuti pelatihan 
Adversity Intelligence karena mereka telah mampis memahami tahapan-tahapan untuk daya juang dalam mengatasi kesulitan yang mempengaruhi peningkatan kebermaknaan hidup. Tahapan tersebut secara umum digolongkan menjadi dua kelompok yang berhubungan lurus, artinya kelompok kedua dapat tercapai bila kelompok pertama dipenuhi. Pertama berpikir positif (Listen, Explore, Analyze) dan dan kedua bertindak positif (Dol). Pemahaman terhadap dua hal tersebut menyebabkan peningkatan kebermaknaan hidup pada remaja panti asuhan setelah mendapatkan pelatihan Adversity Intelligence

\section{Gambar 1. \\ Peningkatan Kebermaknaan Hidup}

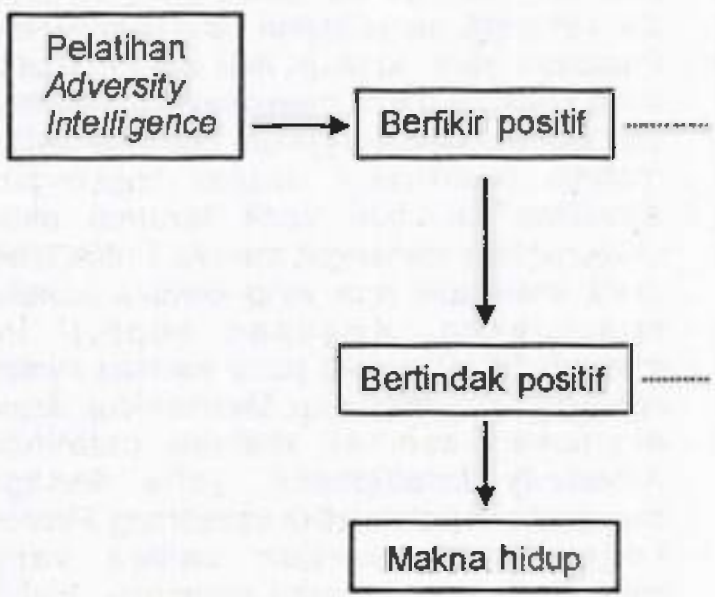

Crumbaugh (Bastaman, 1996)

- Memahami permasalahan (Listen)

- Mencari sumber kesulitan (Explore)

* Mencari bukti masalah tidak dapat dikendalikan, masalah berjangkau luas, masalah berlangsung terus menerus (Analyze) Stoltz (1997)

Mengambil tindakan (Do) Stoltz (1997)

Bervariasinya nilai kebermaknaan hidup setelah posttest pada remaja panti asuhan dapat disebabkan oleh berbagai hal. Cohen dan Milgramm (Sukmana, 2002) mengatakan bahwa manusia mempunyai kemampuan yang terbatas untuk memproses berbagai informasi dari lingkungan. Ketika sejumiah informasi dari lingkungan melebihi kemampuan individus untuk memprosesnya maka terjadilah kelebihan beban informasi dan tindakan pertama yang diambil adalah mengabaikan beberapa rangsang (informasi) yang masuk. Masih menurut Cohen (Sukmana, 2002), dalam situasi seperti ini individu hanya memperhatikan informasi yang dianggap penting saja. Tidak terserapnya keseluruhan materi pelatihan (informasi) sebagai satu kesatuan yang utuh menyebabkan proses pemahamam terhadap kebermaknaan hidup itu sendiri juga tidak berjalan maximal, karena tahapan pelatihan Adversity intelligence tersebut merupakan tahap yang saling berhubungan lurus. Artinya untuk memahami tahap ke 2 (explore) peserta harus memahami tahap pertama dahulu (listen). Peserta dapat menemukan sumber kesulitan (explore), jika ia mengetahui bahwa kesulitan tersebut ada (iisten). Penerimaan yang sebagian dari empat tahap pelatihan Adversity intelligence menyebabkan pemahaman dinamika psikologis hubungan antara Adversity intelligence dan kebermaknaan hidup tidak tercapai sehingga ada subjek yang nilai kebermaknaan hidupnya hanya naik sedikit bahkan ada yang tu run. 


\section{Gambar 2 \\ Dinamika Psikologis}

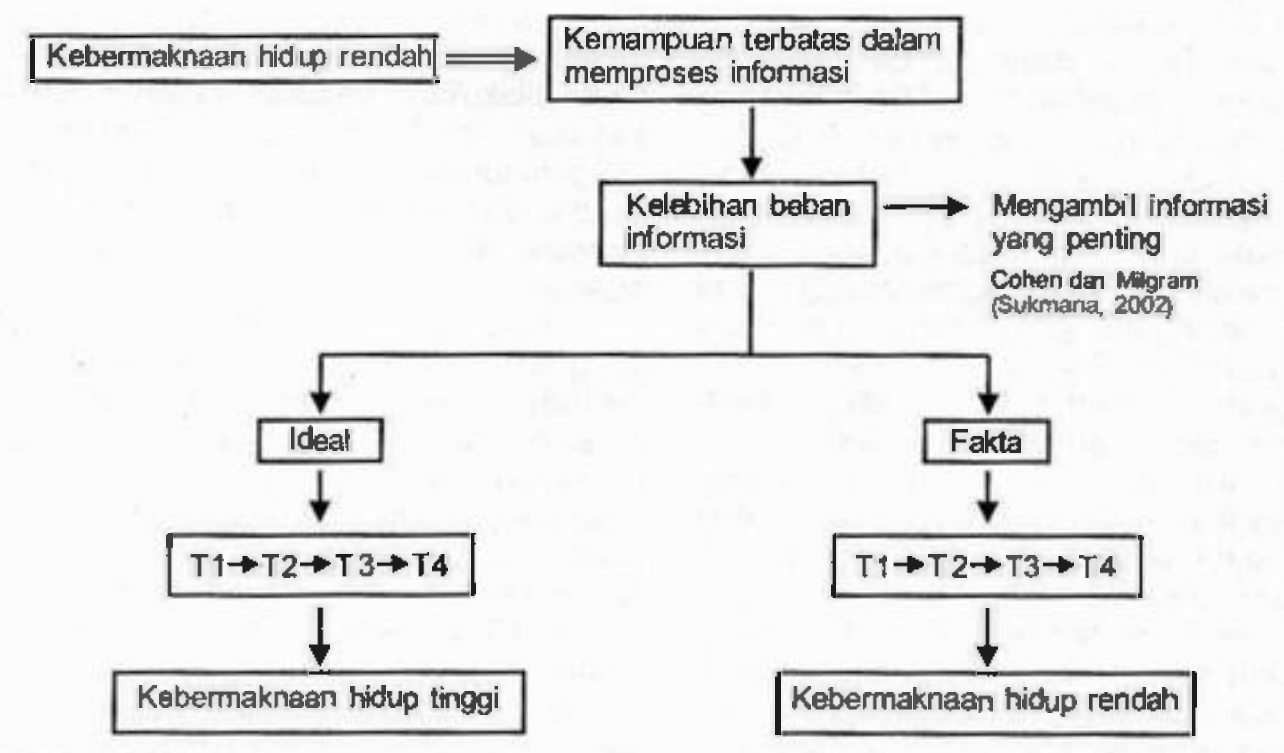

T1 : Tahap $\uparrow$ (Listen)

T2 : Tahap 2 (Explore)

T3 : Tahap 3 (Analyze)

T4 : Tahap 4 (Dol)

Bervariasinya nilai kebermaknaan hidup setelah follow up juga dapat disebabkan oleh berbagai hal. Setiap orang memiliki kemampuan pemahaman yang bervariasi. Ada tpe orang yang langsung dapat memahami dan mengaplíkasikan informasi yang baru saja diterimanya. Kemungkinan sepert ini terjadi pada peserta yang memiliki nilai kebermaknaan hidup tinggi setelah diberikan post-test. Ada tipe orang yang langsung paham tapi ia tidak dapat mengaplikasikan infomasi yang diterimanya saat itu juga, dan ada tipe orang yang tidak dapat langsung paham dan tidak dapat langsung mengaplikasikan informasi yang baru saja diterimanya. Tipe semacam ini memerlukan waktu untuk memahami informasi yang baru saja didapatnya. Tipe kedua dan ketiga barangkali dialami oleh mereka yang memiliki nilai kebermaknan hidup rendah setelah positest dan nilai tinggi setelah follow up. Faktor lingkungan juga dapat mempengaruhi bervariasinya nilai kebermaknaan hidup (turun, naik, tetap) pada subjek penelitian setelah follow up. Cohen (Sukmana, 2002) mengatakan perhatian individu terhadap suatu rangsang tidak bersif at konstan dan mungkin selama waktu tertentu hilang ketika ia melakukan kegiatan lain yang memerlukan perhatian khusus dan lama. Keadaan seperti ini dapat menjelaskan subjek yang mengalami penurunan kebermaknaan hidup setelah followup.

Kelemahan penelitian ini terletak pada subjek penelitian yang memiliki nilai kebermaknan hidup yang terkatagori tinggi. Tingginya nilai kebermaknaan hidup pada subjek penelitian dapat disebabkan oleh pendalaman ibadah yang intens di Panti Asuhan Yatim Muhamadiyah Putra. Sejak tahun 1982 Panti Asuhan Yatim Muhamadiayah Putra mengadakan program pesantrenisasi untuk anak asuhnya. Bastaman (1996) mengatakan jika ibadah dan doa dapat memberikan makna tertentu pada seseorang, apabila orang tersebut melakukannya dengan penuh kesungguhan. 
Al-Qur'an sebagai salah satu panduan umat Islam dalam beribadah dapat membantu seseorang dalam menemukan makna hidupnya. Hal ini diperkuat dengan hasil penelitian Pihasniwati (1998) tentang pengaruh pelatihan penghayatan Al-Qur'an terhadap kebermaknaan hidup yang menunjukkan adanya perbedaan kebermaknaan hidup pada kelompok yang diberi pelatihan penghayatan Al-Qur'an, di mana kelompok yang diberi pelatihan penghayatan AI-Qur'an mengalami penlngkatan kebermaknaan hidup. Masih menurut Bastaman (1996), lbadah yang dlakukan secara khidmat sering menimbulkan perasaan tentram, mantap dan tabah serta tak jarang pula menimbulkan perasaan seakan-akan mendapat bimbingan dalam melakukan tindakan-tindakan penting. Perasaan seperti ini dapat meningkatkan semangat seseorang dalam meraih tujuan hidupnya. Peneliti tidak dapat menentukan sejauh mana pengaruh pelatihan Adversity Intelligence terrhadap peningkatan kebermaknaan hidup remaja panti asuhan yang telah mendapatkan pendalaman agama secara intens.

\section{Kesimpulan dan Saran}

Analisis data terakhir, yaitu dengan membandingkan nilai uj t pada kelompok eksperimen dan kelompok kontrol diperoleh kesimpulan ada pengaruh pelatihan Adversity intellgence terhadap peningkatan kebermaknaan hidup pada remaja panti asuhan. Remaja panti asuhan yang mengikuti pelatihan Adversity Intelligence mengalami peningkatan kebermaknaan hidup. $\mathrm{Hal}$ ini berarti hipotesis penelitian diterima.

Adapun saran penelitian adalah demikian: Subjek penelitian diharapkan dapat mempertahankan nilal kebermaknaan hidup mereka yang terkatagori tinggi. Nilai kebermaknaan hidup yang tinggi menandakan jika mereka telah dapat menemukan sesuatu yang dianggap penting. benar, berharga dan memberikan nilai khusus bagi dirinya.
Saran berikutnya adalah bagi lembaga yayasan. Bagi yayasan panti asuhan diharapkan dapat mempertahankan pembinaan kegiatan agama yang selama ini telah dilakukan. Sebagai variasi, mungkin sesekali perlu diadakan perlombaan pengetahuan agama antar regu yang ada di panti asuhan sehingga dapat meningkatkan motivasi mereka dalam mempelajari ilmu agama.

Bagi peneliti selanjutnya. Bagi peneliti yang tertarik melakukan penelitian dengan metode eksperimen perlu memiliki persiapan yang matang. Ketepatan metode penelitian yang dipakai akan mempengaruhi diterimanya hipotesis penelitian. Peneliti perlu memperhatikan jumlah serta kritetria subjek penelitian. Peneliti perlu menetapkan tim pelatihan yang terlibat. Mereka yang terlibat di dalam pelatihan, harus memiliki komitmen yang tinggi untuk terlibat secara total dalam penelitian ini. Peneliti dan tim pelatihan perlu menyamakan persepsi mengenai penelitian yang akan diadakan, sehingga tujuan penelitian dapat tercapai. Peneliti perlu menegaskan tugas masingmasingtim.

\section{DAFTAR PUSTAKA}

Ancok, D. 2003. Kata Pengantar Dalam Victor E Frankl. Logoterapi : Terapi Psikologi Melalui Pemaknaan Eksistensl. Yogyakarta : Kreasi wacana

Ancok, D. 2002. Out Bound Manangement Training Yogyakarta: Ull Press

Atkinson, R.L.,Atkinson, R.S., Bem, D. 1992 Pengantar Psikologi, edisi sebelas. Batam: Interaksara

Azwar, S. 2002. Penyusunan Skala Psikologi. Yogyakarta: Pustaka Pelajar

Azwar, S. 2001. Dasar-Dasar Psikometri. Yogyakarta: Pustaka Pelajar 
Ayu, M.R. 1997. Cahaya Rumah Kita. Bandung: Mizan

Bethel, S.M. 1994. Mengubah Keadaan. Jakarta: Binarupa Aksara

Bastaman, H. D. 1998. " Adakah Harapan di Tanah Tipis Harapan ? "Jurnal Psikologika, no. 5, thn III, hal 13-17

Bastaman, H. D. 1996. Meraih hidup Bermakna : Kisah pribadi dengan pengalaman tragls. Jakarta: Paramadina

Covey, R.S. 1994. Tujih Kebiasaan Manusia yang Sangat Efektif: Memulihkan Etika Karakter. Jakarta: Gramedia

Daradjat, Z. 1994. Lautan Hikmah Kumpulan Renungan Keagamaan of Harian Republika. Bandung: Mizan

Dewan Penyusun Ensiklopedi Islarn. 1994. Ensiklopedi Islam. Jakarta: Ichtiar Baru Van Hoeve

Echols, J. M dan Shadily. 1995. Kamus Inggris indonesia. Jakarta: Gramedia

Fuhrmann, B. S. 1990. Adolescent, Adolescent. London : Foresrnan and Company

Gosita, A. 1985. Masaiah Pertindungan Anak. Jakarta:Akademika Pressindo

Hadi, S. 2000. Statistik: Jlid 1. Yogyakarta:Andi Offset

Hardjana, A. M. 2001. Training SDM yang Ef sktif. Yogyakarta: Kanisius

Hatini, N. 1999. "Remaja dan Lingkungan Sosialnya". Jumal Anima, no. 1, vol. 15 , hal $76-82$

Hartinl, N. 2001. Deskripsi Kebutuhan Psikologis Pada Anak Panti Asuhan "Jumal Insan Media, no 2 vol 3, hal 109-118
Koeswara, E. 1992. Logoterapi: Psikoterapi Victor Frankl. Yogyakarta: Kanisius

Kartono, K 1986. Pengantar Metodologi Riset Sosial. Bandung: Alurnni

Louis, H. 2003. Hubungan Antara Adversity Intelligence, Kecerdasan Antar Pribadi dan Tipe Kepribadian A Studi Korelasional pada Dosen di Universitas Taruma Negara. Http: II psikologi Untar.com/abstrak/Skripsl. 24 Januari 2004

Lukman, M. 2000."KemandirianAnakAsuh d Panti Asuhan Yati Islam ditinjau dari Konsep diri dan Kompetensi Interpersonal" Jurnal Psikologika Fakultas Psikologl Universitas Islam Indonesia Yogyakartano. 10, thin. V, hal57-74

Mahanani, I. S. 2000. Hubungan Antara Kedemokratisan Pola Asuh Orang Tua Dengan Adversity Quotient. Skripsi (Tidak diterbitkan). Yogyakarta: Fakultas Psikologi Universitas Islarn Indonesia

Mappiare, A 1982. Psikologi Remaja. Bandung : Usaha Nasional

Miller, S.S., M iller, J. A dan Miller. E, 1986. Life Span : The Definitive Guide To Health and Well Boing for The Rest of Your Life. New york: Macmillan Publishing Company

Nanu. 1989. Majalah Amanah: Cipondoh, rumah yatim piatu masa depan. Jakarta

Nadiah. 2003. Pengaruh Pelatihan Manajemen Qolbu Terhadap Peningkatan Problern Solving. Skriosi (Tidak diterbitkan). Yogyakarta: Fakultas Pslkologi UII

Pihasniwati. 1998. Pengaruh Pelatihan Penghayatan Al-Qur'an Terhadap 
Kebermaknaan Hidup. Skripsi (tidak diterbitkan). Yogyakarta: Fakultas Psikologi UGM

Purnomo, H. B. 1990. Memahami dunia anak-anak. Bandung: Mandar Maju

Rahman, A. A 1996.Hubungan Antara Kebermaknaan Hidup dan Daya Tahan Stress Pada Remaja. Skripsi (Tidak Diterbitkan). Yogyakarta: Fakuitas Psikologi Universitas Gadjah Mada

Salim, P dan Sailm, Y. 1991. Kamus Bahasa Indonesia Kontemporer. Jakarta: Modern Engilsh Press

Sarwono, S. W. 2002. Psikologi Remaja. Jakarta: Raja Grafindo Persada

Sobur, A 1991. Komunikasi Orang Tua dan Anak. Bandung :Angkasa Bandung

Srisusilawati. 2000. Motif Berprestasi Ditinjau dari Konsep Diri dan Kebermaknaan Hidup pada Mahasisswa Fakultas Hukum UII. Skripsi (Tidak diterbitkan). Yogyakarta: Fakultas Psikologi Universitas Isiam Indonesia

Stoltz, P. G. 2000. Faktor Penting dalam Meraih Sukses : Advrsity Quotient Mengubah Hambatan Menjadi Peluang. Jakarta: Grasindo
Sukmana, O. 2002. Dasar-dasar Psikoiogi Lingkungan. Jakarta: Bayu Media

Suryabrata, S. 1992. Metodologi Penelitian. Jakarta: Rajawali Press

Suyanti, V. E., Setiasih., Mangunhardjana,A. 2002. Pengaruh Pelathan Emotional Literacy Terhadap Kecerdasan Emosional Remaja "Jurnal Psikologi Anima, vol. 17, no 3, hai 243-256

Steinem, G. 1995. Pedoman Tentang Harga Diri: Mengubah Keadaan untuk Mencapai Puncak Sukses. Jakarta: Binarupa Aksara

Tjundjing, S. 2001. "Hubungan amiara /Q, EQ dan $A Q$ dengan prestasi studi pada siswa $S M U^{n}$ Jurnal Psikoiogl Anima, vol.17.no.1,hal 69-92

Widiastuti, E 1995. Perbedaan Kemampuan Menjalin Hubungan Interpesonai Antar Remaja ditinjau dari Tempat Pengasuhan. Skripsi (tidak di terbitkan). Yogyakarta: Fakultas Psikologi UGM

Zainurrofikoh. 2000. Hubungan Antara Kebermaknaan Hidup dengan Harga Diri Pada Mahasiswa. Skrijosi (Tidak diterbitkan). Yogyakarta: Fakultas Psikologi Universitas Yogyakarta 